\title{
INCIDENCE OF E.COLI O157:H7 IN SOME DAIRY PRODUCTS
}

\author{
Asmaa M. Elbastawesy *, Azza M.M. Deeb ${ }^{* *}$, Nehad I. El-desoky* \\ * Food control department, Animal Health Research Institute, \\ KaferEl-Sheikh Branch.

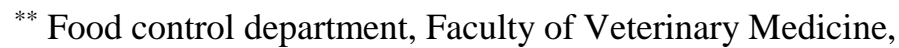 \\ Kaferelsheikh University, Egypt.
}

\begin{abstract}
A total of 104 dairy product samples (33 kareish cheese, 38 yoghurt and 33 sour cream) were randomly purchased from different shops, markets and street vendors in Kafer El-Sheikh city for isolation and serological identification of E.coli serotype O157:H7. 24.2\%, 21\% and $42.2 \%$ of kariesh cheese, yoghurt and sour cream respectively, contained E.coli. All the suspected strains were serologically identified for E.coli O157:H7, using E.coli O157:H7 kits. The organism could be detected in 3\% of examined kareish cheese while could not be detected in yoghurt and sour cream examined samples. E.coli serotypes of O157:H7, O111:H4, O26:H11, O114:H21,O86, O55:H7,, O125:H21,O126, O128:H2, and O124 were serologically identified by percentages of $(12.5 \%, 0$ and 0$),(25 \%, 25 \%$ and $26.6 \%)$, (12.5\%, $12.5 \%$ and $13.3 \%),(12.5 \%, 12.5 \%$ and $6.7 \%),(0,12.5 \%$ and 0$),(0,12.5 \%$ and $6.7 \%),(0,0$ and $20 \%),(12.5 \%, 0$ and 0$)$, $(12.5 \%, 25 \%$ and $20 \%)$ and $(12.5 \%, 0$ and $6.7 \%)$ of the isolates of each examined kareish cheese, yoghurt and sour cream samples respectively.

Based on the obtained results in the current study, the fermented dairy products were a possible source of food poisoning caused by E.coliO157:H7.So, application of strict hygienic measures during processing of some dairy products and restriction of selling the dairy products to healthy authorized shops with high quality measures being very important.
\end{abstract}

Key words: E.coli, E.coli O157:H7, Dairy products, serolgical identification. 


\section{INTRODUCTION}

Milk and dairy products are considered as the most perfect food for human especially for infants and mature human beings as they provide them with all nutrients required for rapid growth and prevent or reduce risks of many nutritional deficiency diseasesas well (Marshall et al., 2003). On the other hand,dairy products have been shown to be an ideal media for growth and multiplication of microorganisms (Wieneke et al., 1993),improper handling and the use of improper storage temperatures are factors that contribute to the potential hazard of the dairy products (Yusuf et al., 2013).

E.coli is the main food poisoning microorganisms associated with raw milk products such as cheese, sour cream and yoghurt (Verraes et al., 2015) and was considered as an index of fecal contamination until 1950 but this perspective was changed with the discovery of pathogenic types that could cause deaths in both humans and animals (Nataro and Kaper, 1998).

E. coli $0157: H 7$ is one of the foodborne pathogens of concern for the dairy industry. Raw dairy products have been identified as an important vehicle for the transmission of this pathogen (Heuvelink et al., 1998). E. coli O157:H7is responsible for bloody or non- bloody diarrhea, which may be complicated by hemorrhagic colitis and severe renal and neurological sequelae, including hemolytic uremic syndrome (HUS) (Lynn et al., 2005).

Therefore, the present study was undertaken to determine the prevalence of E.coliO157:H7 and other E.coliin someDairy products. 


\section{MATERIALS AND METHODS}

\section{Collection and preparation of samples:}

A total of 104 dairy product samples (33 kareish cheese, 38 yoghurt and 33 sour cream) were randomly purchased from different shop, markets and street vendors in Kafer El-Sheikh City. The collected samples were transferred in ice box and examined immediately after arrival to the laboratory (Animal Health Research Institute, Kafer ElSheikh branch).

\section{Isolation of E.coli O157:H7 according toFDA, (1995):}

Twenty five grams of prepared samples were added to $225 \mathrm{ml}$ of Enteroheamoragic E. Coli enrichment broth (EEB), homogenized then incubated at $37^{\circ} \mathrm{C}$ for 24 hours.Aloopful from the incubated broth was streaked onto Cefixime Tellurite Sorbitol Mac Conkey agar (CT-SMAC) plates and all plates were incubated at $37^{\circ} \mathrm{C}$ for 24 hours. Transparent, colorless with a weak pale brownish appearance (sorbitol negative) colonies were picked up on nutrient agar slopes as presumptive E.coli O157:H7. The purified colonies were subjected for further identification.

\section{Biochemical identification of bacterial isolates:-}

The isolated organisms were identified biochemically according to Macfaddin, (2000).

\section{Serological Identification of E.coli isolates:}

According to Kok et al., (1996) the isolates were serologically identified by using rapid diagnostic E.coli antisera sets DENKA SEIKEN Co., Japanfor diagnosis of E.coli. 


\section{RESULTS}

Table (1): Incidence of $E$. coli $O 157: H 7$ in the examined dairy products samples:

\begin{tabular}{|c|c|c|c|c|c|c|c|}
\hline \multirow[t]{2}{*}{$\begin{array}{l}\text { Type of } \\
\text { samples }\end{array}$} & \multirow[t]{2}{*}{$\begin{array}{c}\text { No. of } \\
\text { examined } \\
\text { samples }\end{array}$} & \multicolumn{2}{|c|}{$\begin{array}{l}\text { Suspected positive } \\
\text { samples according to } \\
\text { colonial characters }\end{array}$} & \multicolumn{2}{|c|}{$\begin{array}{c}\text { Suspected positive } \\
\text { samples according to } \\
\text { biochemical } \\
\text { identification }\end{array}$} & \multicolumn{2}{|c|}{$\begin{array}{l}\text { Positive samples } \\
\text { according to } \\
\text { serological } \\
\text { identification }\end{array}$} \\
\hline & & No. & $\%$ & No. & $\%$ & No. & $\%$ \\
\hline Kariesh cheese & 33 & 10 & 30.3 & 8 & 24.2 & 1 & 3 \\
\hline Yoghurt & 38 & 12 & 31.5 & 8 & 21 & 0 & 0 \\
\hline Sour cream & 33 & 15 & 45.4 & 14 & 42.4 & 0 & 0 \\
\hline Total & 104 & 37 & 35.57 & 30 & 28.84 & 1 & 0.96 \\
\hline
\end{tabular}

Table (2): Frequency distribution of E.coli serotypes other than E.coli O157:H7

\begin{tabular}{|c|c|c|c|c|c|c|c|}
\hline \multirow{2}{*}{$\begin{array}{c}\text { Types of } \\
\text { E.coli }\end{array}$} & \multirow{2}{*}{ E.coliserotypes } & \multicolumn{2}{|c|}{ Kariesh cheese isolates } & \multicolumn{2}{|c|}{ Yoghurt isolates } & \multicolumn{2}{|c|}{ Sour cream isolates* } \\
\hline & & No. & $\% * *$ & No. & $\% * *$ & No. & $\% * *$ \\
\hline \multirow{3}{*}{ EHEC } & O157 : H7 & 1 & 12.5 & 0 & 0 & 0 & 0 \\
\hline & O111 :H4 & 2 & 25 & 2 & 25 & 4 & 26.6 \\
\hline & O26 : H11 & 1 & 12.5 & 1 & 12.5 & 2 & 13.3 \\
\hline \multirow{3}{*}{ EPEC } & O114:H21 & 1 & 12.5 & 1 & 12.5 & 1 & 6.7 \\
\hline & O86 & 0 & 0 & 1 & 12.5 & 0 & 0 \\
\hline & $\mathrm{O} 55: \mathrm{H} 7$ & 0 & 0 & 1 & 12.5 & 1 & 6.7 \\
\hline \multirow{3}{*}{ ETEC } & O125:H21 & 0 & 0 & 0 & 0 & 3 & 20 \\
\hline & O126 & 1 & 12.5 & 0 & 0 & 0 & 0 \\
\hline & $\mathrm{O} 128: \mathrm{H} 2$ & 1 & 12.5 & 2 & 25 & 3 & 20 \\
\hline EIEC & $\mathrm{O} 124$ & 1 & 12.5 & 0 & 0 & 1 & 6.7 \\
\hline \multicolumn{2}{|c|}{ Total } & 12 & 100 & 8 & 100 & 15 & 100 \\
\hline
\end{tabular}

* One sample of sour cream represented by two isolates.

** Percent was calculated according to the number of isolates of each product.

$\overline{\text { Kafrelsheikh Vet. Med. J. Vol. } 14 \text { No. } 1 \text { (2016) }}$ 


\section{DISCUSSION}

E.coli is a common gram negative food borne enteric pathogen causing foodborne gastro-enteritis worldwide. From the results obtained in table (1) $30.3 \%, 31.5 \%$ and $45.4 \%$ of examined kariesh cheese, yoghurt and sour cream samples, respectively, showed the characters of E.coli O157:H7 on Cefixime Tellurite Sorbitol Mac Conkey agar (pale colonies) plates. After the biochemical identification of suspected isolates, $24.2 \%, 21 \%$ and $42.4 \%$ of examined kariesh cheese yoghurt and sour cream samples were presumed E.coli O157:H7. Serological identification of the suspected isolates, E.coli $\mathrm{O} 157: \mathrm{H} 7$ proved to be found in $3 \%$ of examined kariesh cheese samples, while it failed to be detected in any yoghurt and sour cream samples.

E.coli $\mathrm{O} 157: \mathrm{H} 7$ has been isolated from kariesh cheese in variable percentages ranged from $6.7 \%$ to $20 \%$ (El-Awadi, 2004, El Sayed et al., 2011andIbrahim et al., 2015) While, Ibrahim and Sobeih, (2006); Tekinşen and Özdemir, (2006) and prencipe et al.,(2010) could not isolate the organism from any of the examined cheese samples. On the other hand, Rahimi et al., (2011) and Ahmed and Shimamoto, (2014) could not isolate the organism from yoghurt samples. While Amany and Marcel, (2008) and Dehkordi et al., (2014) isolated it with percentage $42 \%$ and $26 \%$,respectively from yoghurt samples. The organismcould be isolated in percentages varied from $6 \%$ to $20 \%$ in sour cream (Elkosi, 2001, Eman, 2011and Daood, 2013). 
E. coli $0157: H 7$ has an optimum growth at $\mathrm{pH}$ of around 7 and is able to grow in a pH range between 4.5 and 9. Furthermore, some strains of $E$. coli $0157: H 7$ are acid-resistant, being able to withstand $\mathrm{pH}$ values as low as 3.Thus, the lowest $\mathrm{pH}$ of cheese will not inactivate E. coli O157:H7 or other STEC (Shiga Toxin producing E.coli). Acid adaptation to the non-lethal $\mathrm{pH}$ in the cheese may promote greater survival of E. coli $\mathrm{O} 157: \mathrm{H} 7$ during passage through the acid environment of the stomach (Jordan et al., 1999), while inyoghurt E.coli O157:H7 growth is affected by $\mathrm{PH}$ and temperature of the storage. Decreasing of temperature to $4^{\circ} \mathrm{C}-8{ }^{\circ} \mathrm{Cduring}$ yoghurt storage slightly affect the growth of E.coli O157:H7,whileits low PH level affect the growth of nonpathogenic E.coli but E.oli O157:H7 was more resistant to the higher decrease in PH to level between 4 to 3.92 (Bachrouri et al., 2002). De Araújo and Giugliano, (2001) attributed the presence of STECin dairy products to the fact that milk carries a number of immune factors (principally $\operatorname{IgA}$ ) and non-immune factors (lactoferrin and various free secretory components) that specifically hinder the adherence and subsequent proliferation of STEC on certain cell substrates. But the resistance exhibited by $\mathrm{O} 157: \mathrm{H} 7$ may be related to certain properties characteristic of this bacterium, not found in other STEC strains. O157:H7 has been reported to survive in refrigerated milk at temperatures ranging between $7{ }^{\circ} \mathrm{C}$ and $17{ }^{\circ} \mathrm{C}$ (Heuvelink et al., 1998), and may multiply even at $8{ }^{\circ} \mathrm{C}$ (Massa et al., 1999). Resistance to acid $\mathrm{pH}$ has been linked to the presence of certain genes, exclusive to the O157:H7 serotype, whose products ensure an extraordinary degree of acid tolerance (Lin et al., 1996). Also, the fat molecules may protect STEC during such heat treatment (Erickson and Doyle, 2007) allowing its survival in sour cream so the sour cream may cause health hazard as it have high fat content. 
The result in table (2) showed that different E.coli serotypes as EHEC serotypes O157:H7,O111:H4 and O26:H11 were detected in percentage of $12.5 \%, 25 \%$ and $12.5 \%$ from the isolates obtained from kariesh cheese samples, while E.coli $\mathrm{O} 157: \mathrm{H} 7$ failed to be detectedfrom yoghurt and sour cream. Other serotypes of E.coli (O111:H4 and $\mathrm{O} 26: \mathrm{H} 11)$ could be isolated with percentages of $25 \%$ and $12.5 \%$ of yoghurt isolates and $26.6 \%$ and $13.3 \%$ of sour cream isolates. EPE Cserotypes O114:H21and O55:H7were detected in kariesh cheese, yoghurt and sour cream isolates with percentages of $(12.5 \%, 12.5 \%$ and $6.7 \%)$ and $(0,12.5 \%$ and $6.7 \%)$ respectively, while 086 was only detected in yoghurt samples with a percentage of 12.5\%.ETEC serotypes O125:H21,O126 and O128:H2 could be detected in the examined kariesh cheese with percentages of $0,12.5$ and $12.5 \%$ respectively, while for sour cream isolates with percentages of 20,0 and $20 \%$. Concerning yoghurt isolates, $\mathrm{O} 128: \mathrm{H} 2$ was the only serotype of ETEC which detected by percentage of $25 \%$. EIEC represented in O124 wasdetectedin isolates of kariesh cheese and sour cream with percentage $12.5 \%$ and $6.7 \%$.

The studies of Nemr, (2005); Rey et al., (2006); Abou ElMakarem, (2009); Fadel and Ismail, (2009) and Madic et al., (2011) investigated the distribution of other different serotypes of E.coli (O111 :H4;O55:H7; O126; O125:H21; O26:H11; O114:H21;O128:H2 and O86) isolated from kareish cheese. While, the study of Dehkordi et al., (2014) recorded the presence of E.coli O26:H11in yoghurt with percentage of $12.5 \%$. 
E.coli strains were classified according to the presence of virulence factors to EHEC, EPEC, ETEC and EIEC Holko et al., (2006). Escherichia coli cause a range of food illness as gastroenteritis and diarrhea but EHEC may also cause other type of severe illness as hemolytic uremic syndrome. One other hand, EPEC are a leading cause of infantile diarrhea in developing countries. While, Enterotoxin-producing E.coli (ETEC) are one of the main causative agents of travel diarrhea in adults (Natro and Kaper, 1998).

Food-borne illnesses linked to non-O157 STEC, such as serotypes O26, O45, O111, O103, O145 and O121, have been increasing according to the data reported by Centers for Disease Control and Prevention (CDC) (Hoefer et al., 2011).

Based on the obtained results in the current study, it was concluded that acidic fermented dairy products were a possible source of food poisoning caused by E.coliO157:H7 beacause this pathogen able to survive and grow in this products with its conditions of acidity and storage temperature.

In conclusion, high quality milk and proper condition of processing and storage should be considered in dairy product manufacturing as it is have a great role of the products contamination. So, restrict hygienic measures during processing of dairy products and restriction of its selling to healthy authorized shops with high quality measures being very important. 


\section{REFERENCES}

- Abou El-Makarem, H. S. M. (2009): Plasmid profile from several pathogenic microorganisms' strains isolated from market Kareish cheese.', MV.Sc. Thesis, Fac. Veterinary Medicin Alexandria University.

- Ahmed, A. M. and Shimamoto, T. (2014): Isolation and molecular characterization of Salmonella enterica, Escherichia coli O157: H7 and Shigella spp. from meat and dairy products in Egypt. International journal of food microbiology, 168, 57-62.

- Amany, M. s. and Marcel, F. G. (2008): occurance of Escherichia coli in some Egyptian dairy prouducts with special refrence to serotypeO157:H7. milchwissen Schalf, 53 (12), 676-679.

- Bachrouri, M., Quinto, E. and Mora, M. (2002): Survival of Escherichia coli O157: H7 during storage of yoghurt at different temperatures. Journal of food science, 67, 1899-1903.

- Daood, N. (2013): Detection and antimicrobial susceptibility of $E$. coli O157: $\mathrm{H} 7$ in raw bovine milk, some of dairy products and water samples. Damascus Univerisity Journal for daisic scienceences, 23 (1): 21-35.

- De Araújo, A. N. and Giugliano, L. G. (2001): Lactoferrin and free secretory component of human milk inhibit the adhesion of enteropathogenic Escherichia coli to HeLa cells. BMC microbiology, 1,25 .

- Dehkordi, F. S., Yazdani, F., Mozafari, J. and Valizadeh, Y. (2014): Virulence factors, serogroups and antimicrobial resistance properties of Escherichia coli strains in fermented dairy products. BMC research notes, 7, 217. 
- El-Awadi, I. A. (2004): Enteropathogenic Escherichia coli (E. coli O157:H7) in milk and dairy products. . Ph.D. Thesis, Faculty of Veterinary Medicine, Mansoura Univ., Egypt.

- El-Sayed, M.,Hosny, I., El Kholy, W.,El Dairouty,R. and Mohamed, S. H.(2011): Microbiological evaluation of Egyptian white soft cheeses style. Journal of American Science, 7(5):57-529.

- Elkosi, M. (2001): Occurance of some enteric pathogens and their indicators in some Egyption raw milk prouducts Assiut Veterinary Medicin Journal, 45 (89), 48-61.

- Eman, M. E. (2011): Toxicoinfection organisms in milk and some dairy products sold in Dakahlia Governorate. Ph.D. Thesis, Faculity of Veterinary Medicine, Mansoura Univ. .

- Erickson, M. C. and Doyle, M. P. (2007): Food as a vehicle for transmission of Shiga toxin-producing Escherichia coli. Journal of Food Protection, 70, 2426-2449.

- Fadel, H. and Ismail, J. (2009): Prevalence and significance of Staphylococcus aureus and Enterobacteriaceae species in selected dairy products and handlers. International Journal of Dairy Science, 4 (3): 100-108.

- FDA (1995): Bacteriological Analytical Manual, 8th Ed Chapter 4,. AOAC International, Arlington Va.USA.

- Heuvelink, A., Bleumink, B., Van den Biggelaar, F., Te Giffel, M., Beumer, R. and De Boer, E. (1998): Occurrence and survival of verocytotoxin-producing Escherichia coli 0157 in raw cow's milk in The Netherlands. Journal of Food Protection, 61, 1597-1601. 
- Hoefer, D., Hurd, S., Medus, C., Cronquist, A., Hanna, S., Hatch, J., Hayes, T., Larson, K., Nicholson, C. and Wymore, K. (2011): Laboratory practices for the identification of Shiga toxin-producing Escherichia coli in the United States, FoodNet Sites, 2007. Foodborne pathogens and disease, 8, 555-560.

- Holko, I., Bisova, T., Holkova, Z. and Kmet, V. (2006):Virulence markers of E.coli strains isolated from traditional cheeses made from unpasteurised sheep milk in Slovakia:, Food Control,17(5): 393-396.

- Ibrahim, E. M. A. and Sobeih, M. A.(2006): Diarrhoegenic E. coli in Kareish cheese manufactured by different methods with special reference to E. coli O157:H7. . Minufiya Veterinary Medicine Journal, 4, 169-178.

- Ibrahim, G. A., Sharaf, O. M. and El-Khalek, A. B. A.(2015): Microbiological Quality of Commercial Raw Milk, Domiati Cheese and Kareish Cheese. Sciences,5, 171-176.

- Jordan, K. N., Oxford, L. and O'Byrne, C. P.(1999): Survival of lowpH stress by Escherichia coli O157: H7: correlation between alterations in the cell envelope and increased acid tolerance. Applied and Environmental Microbiology,65, 3048-3055.

- Kok, T., Worswich, D. and Gowans, E .(1996): Some serological techniques for microbial and viral infections. In Practical Medical Microbiology (Collee, J.; Fraser, A.; Marmion, B. and Simmons, A., eds.), 14th ed., Edinburgh, Churchill Livingstone, UK.

- Lin, J., Smith, M. P., Chapin, K. C., Baik, H. S., Bennett, G. N. and Foster, J. W. (1996): Mechanisms of acid resistance in enterohemorrhagic Escherichia coli. Applied and Environmental Microbiology 62, 3094-3100. 
- Lynn, R. M., O’Brien, S. J., Taylor, C. M., Adak, G. K., Chart, H., Cheasty, T., Coia, J. E., Gillespie, I. A., Locking, M. E. and Reilly, W. J.(2005): Childhood hemolytic uremic syndrome, United Kingdom and Ireland. Emerging infectious diseases, 11, 590-596.

- Macfaddin, J. F. (2000): Biochemical tests for identification medical bacteria. Warery press, INC. Baltimore, Md. 21202 USA.

- Madic, J., Vingadassalon, N., de Garam, C. P., Marault, M., Scheutz, F., Brugère, H., Jamet, E. and Auvray, F. (2011): Detection of Shiga toxin-producing E.coli serotypes O26: H11, O103: H2, O111: H8, O145: H28, and O157: $\mathrm{H} 7$ in raw-milk cheeses by using multiplex real-time PCR.Applied and Environmental Microbiology, 77 (6): 2035-2041.

- Marshall, T. A., Levy, S. M., Broffitt, B., Warren, J. J., Eichenberger-Gilmore, J. M., Burns, T. L. and Stumbo, P. J.(2003): Dental caries and beverage consumption in young children. Pediatrics, 112, e184-e191.

- Massa, S., Goffredo, E., Altieri, C. and Natola, K.(1999): Fate of Escherichia coli O157: H7 in unpasteurized milk stored at 8 C. Letters in Applied Microbiology 28, 89.

- Nataro, J. P. and Kaper, J. B. (1998): Diarrheagenic E.coli.Clinical microbiology reviews,11(1): 142-201.

- Nemr, M., M. (2005): Study on the incidence of E. coli in raw milk and milk products with special reference to the intero-pathogenic serotypes. M.Sc. Thesis, Faculty of Veterinary Medicine, Assiut Univ.

- prencipe, V., Migliorati, G., Matteucci, O., Calistri, P., Giannatale, E. and (2010): assessment of hygienic quality of some types of cheese sampled from retail outlets. Veterineria Italiana,46(2), 221-31,233-42. 
- Rahimi, E., Chaleshtori, S. S. and Parsaei, P.(2011): Prevalence and antimicrobial resistance of Escherichia coli $\mathrm{O} 157$ isolated from traditional cheese, ice cream and yoghurt in Iran. African Journal of Microbiology Research,5, 3706-3710.

- Rey, J., Sánchez, S., Blanco, J., de Mendoza, J. H., de Mendoza, M. H., García, A., Gil, C., Tejero, N., Rubio, R. and Alonso, J. (2006): Prevalence, serotypes and virulence genes of Shiga toxin-producing Escherichia coli isolated from ovine and caprine milk and other dairy products in Spain. International journal of food microbiology, 107, 212-217.

- Tekinşen, K. K. and Özdemir, Z. (2006): Prevalence of foodborne pathogens in Turkish Van otlu (Herb) cheese. Food Control,17, 707-711.

- Verraes, C., Vlaemynck, G., Van Weyenberg, S., De Zutter, L., Daube, G., Sindic, M., Uyttendaele, M. and Herman, L. (2015): A review of the microbiological hazards of dairy products made from raw milk. International Dairy Journal, 50, 32-44.

- Wieneke, A., Roberts, D. and Gilbert, R. (1993): Staphylococcal food poisoning in the United Kingdom, 1969-90. Epidemiology and infection, 110, 519-531.

- Yusuf, A., Abdul, T., Hamid, T. A. and Yusuf, M.(2013): Assessment of The Bacteriological Quality of Ice Cream Offered for Public Consumption in Bauchi. Nigeria. IOSR Journal of Pharmacy,3, 25-30. 
مدى نو اجد ميكروب الإيشيرشيا كو لاى 0157:H7 فى بعض منتجات الألبان

أسماء مصطفى عبد المحسن البسطويسى"، عزة ميرغنى محمد ديب" "نهاد إبراهيم الدسوقى "

$$
\begin{aligned}
& \text { " قسم مراقبة الأغنية- معهُ بحوث صحة الحيوان - فرع كفر الثبخ } \\
& \text { " قسم مراقبة الأغنية -كلية الطب البيطني - جامعة كفر الثيخ }
\end{aligned}
$$

تم تجميع 104 عينـة من منتجات الألبان (33 من الجبن القريش ،38 من الزبادي و33من القتدة الحامضـة) جمعت عشوائيا من مختلف المتاجر والأسواق والباعة الجائلين في مدينة كفرالثيخ لعزل وتصنيف ميكروب الإيشيرشيا كولاىO157:H7 وقد تبين انه من خلال الفحص السيرولوجى تم عزل ميكروب الإيشيرشيا القولونيـةO157: H7 من 30 من عينات الجبن القريش بينما لم يتم عزل الميكروب من عينات الزبـادى او القثـدة الحامضـهـ ومن خـلال الفحص السيرولوجى تم عزل بعض تص الانـواع الاخـرى مـن الأنمـاط المصـلية القولونيــة منهـ O157:H7 O26:H11 ، O111:H4

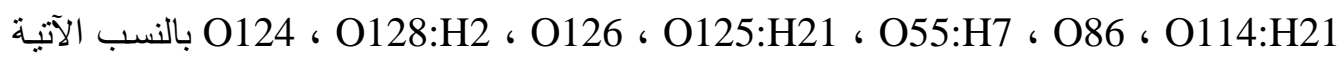
، 0$)$ ، 6.7 , 12.5 ، 12.5$)$ 12.5 (12.5 ، 0 و 6.7) من العترات المعزولة من الجبن القريش ، الزبادى والقتدة الحامضة على التوالى. واستتادا إلى النتائج الني تم الحصول عليها في الدراسة الحالية،نبين ان منتجات الألبان المتخمرة من الممكن أن تكون مصدرا للتسمم الغذائي الناجم عن الايشريشيا القولونية O157: H7. لذلك يوصى باتخاّذ الاحتياطات الصحية أثناء تصنيع و تخزين وتداول منتجات الألبان وكذلك بيع منتجات الألبان في المحلات التجارية المصرح بها صحيا بمعايير الجودة العالية. 